\title{
Coautores \\ urbanos: \\ cidadãos formais, \\ marginalizados \\ e ativistas urbanos
}

\author{
Gabrielle Rocha*
}

Resumo o presente artigo tem como objeto de estudo os coautores urbanos, responsáveis por exemplificar através do cotidiano o conceito de coautoria urbana. Estes coautores podem atuar através do urbanismo de topo (quando detém algum tipo de poder, seja ele econômico, social ou político) e do urbanismo de base (quando detém pouco ou nenhum poder, ou são menos favorecidos). Neste artigo, é priorizada a atuação da base, na qual foram percebidas semelhanças entre alguns grupos em suas formas de apropriação, visões de cidade e experiências, formando, então, as chamadas camadas coautoras. Assim, são trabalhadas as territorialidades, micropolíticas, corpos e papéis de três camadas coautoras da base: os cidadãos formais, os cidadãos marginalizados e os ativistas urbanos.

Palavras-chave: coautores urbanos, apropriações, micropolíticas.

\section{Coautores urbanos: ciudadanos formales, marginados y activistas urbanos}

Resumen El presente artículo tiene como objeto de estudio los coautores urbanos, responsables por ejemplificar a través de lo cotidiano el concepto de coautoría urbana. Estos coautores pueden actuar a través del urbanismo desde arriba (cuando tiene algún tipo de poder, ya sea económico, social o político) y del urbanismo de base (cuando tiene poco o ningún poder, o son menos favorecidos). En este artículo, se prioriza la actuación desde la base, en la cual se percibieron semejanzas entre grupos, en sus formas de apropiación, visiones de ciudad, experiencias, formando las llamadas capas de coautoría. Así, se trabajan las territorialidades, micropolíticas, cuerpos y papeles de tres capas coautoras de la base: ciudadanos formales, ciudadanos marginados y activistas urbanos.

Palabras clave: coautores urbanos, apropiaciones, micropolíticas.

\section{Urban co-authors: formal citizens, marginalized citizens and urban activists}

\begin{abstract}
The object of study in the present paper are the urban coauthors, responsible for exemplifying through the everyday the concept of urban co-authorship. These coauthors can act through top-down urbanism (when it holds some kind of power, weather it is economic, social or political) and bottom-up urbanism (when it holds little or no power, or are less favored). In this article, it is prioritized the performance of the bottom-up co-authors, in which similarities were perceived between some groups in their forms of appropriation, visions of city and experiences, forming the coauthors layers. Therefore, the territorialities, micropolitics, bodies and roles of three bottom-up coauthors layers are worked: the formal citizens, the marginalized citizens and the urban activists.
\end{abstract}

Keywords: urban coauthors, appropriations, micropolitics. 
A

s diferenças constroem as cidades, podendo torná-las plurais. Jacobs (2011) escreve sobre a necessidade da existência destas diferenças "[...] aflorando em várias direções para não perdermos a orientação" (JACOBS, 2011, p. 247). Os espaços podem ser ocupados de diferentes formas por diferentes corpos cidadãos, orientando e tornando a cidade viva, seja quando seu objetivo ou uso original é modificado de forma subersiva através da apropriação ou não, quando faz-se o uso esperado/pré-definido para aquele local. Dessa forma, pode-se trazer a ideia que estes cidadãos dividem de alguma forma a autoria do urbano, a partir do momento em que se compreende que, sem eles, o espaço não seria lugar.

Assim, a coautoria urbana é a construção de novas cidades a partir dos cidadãos (ROCHA, 2018), seja como resposta a uma imposição do urbanismo implementado por detentores de algum poder (político, econômico ou social), seja como forma de chamar a atenção para a falta de projetos, seja como uma forma de usar a cidade da maneira pré-determinada.

Este artigo tem, então, como objetivo desenvolver a ideia de coautoria através da apresentação e do estudo da forma de apropriação do espaço urbano pelas pessoas. A pesquisa ${ }^{1}$ teve início através de estudo teórico, de observação e de experiências prévias, na qual foi analisado o urbanismo de topo (feito por pessoas que detém algum tipo de poder, de cima para baixo), o urbanismo de base (feito por pessoas que tem pouco ou nenhum poder, debaixo para cima) e os conflitos entre ambos, que também podem gerar o conceito de coautoria. Dentro destas duas formas de se construir o urbano, foram percebidos alguns grupos de pessoas (vulgo coautores) que apresentaram similaridades, seja em seus interesses, experiências, necessidades e/ou visões de cidade. Estes grupos foram organizados para leitura da coautoria, sendo, então, chamados "camadas coautoras" nesta pesquisa. Neste artigo, não serão trabalhadas as camadas coautoras pertencentes de forma majoritária ao primeiro grupo e sim, o segundo grupo - a base - terá prioridade. A nomenclatura 'camadas' foi escolhida por sua possível sobreposição ou articulação, de forma que alguns dos coautores podem ser parte de uma ou de várias camadas.

As diferenças mencionadas anteriormente são responsáveis pela vida nas cidades e por sua percepção e identidade. Ao investigar estas infinitas possibilidades, há uma revelação das multiplicidades sobrepostas, onde "suas identidades, modos, formas, categorias e tipos recombinam-se no cinza das ruas. Como resultado, as narrativas das cidades são tanto evidentes quanto enigmáticas. Conhecê-las é sempre experimental" (HOLSTON, 1996, p. 243). A investigação é sempre rica, se aberta à qualquer resposta inesperada e, como Holston escreveu, é um experimento contínuo e enigmático.

* Gabrielle Rocha é Arquiteta e Urbanista, Mestre em Urbanismo pelo PROURB/Universidade Federal do Rio de Janeiro, ORCID $<$ https://orcid.org/0000-00020831-0842>. O enigma parte das diferentes subjetividades destas camadas, sendo adaptadas e reformuladas a partir dos diferentes tempos que acontecem na cidade, sendo eles "[...] passados ou futuros que irrompem, emergem no presente e provocam esse choque, uma faísca, de tempos heterogêneos" (JACQUES, 2018, p. 223). 


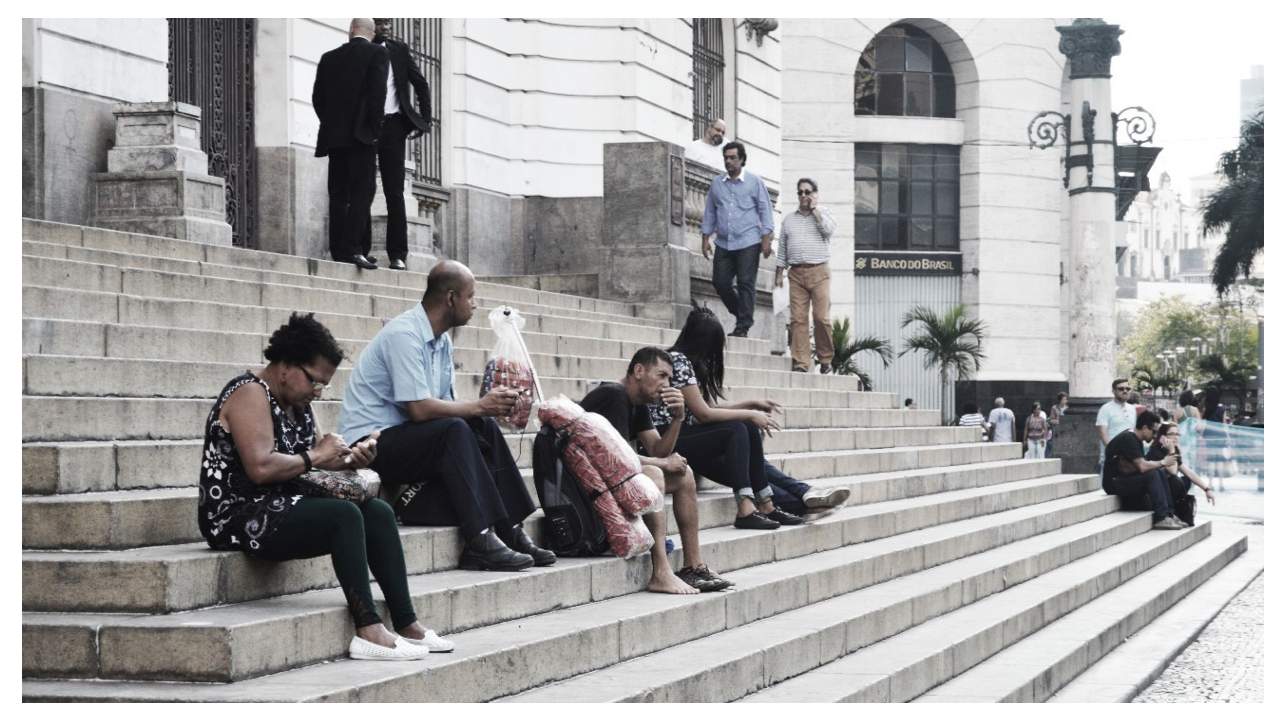

Figura 1: Degraus como espaço de circulação (uso original), espera e assento. Fonte: Autora, 2016.

\footnotetext{
1 Este artigo constitui parte do capítulo 2 da dissertação de mestrado "Coautoria Urbana: A funcionária, o produtor e o camelô", desenvolvida por esta autora no mestrado acadêmico do PROURB-FAU/UFRJ com bolsa fornecida pelo CNPq. O trabalho também foi realizado com apoio da Coordenação de Aperfeiçoamento de Pessoal de Nível Superior - Brasil (CAPES) - Código de Financiamento 001.
}

Devido à heterogeneidade das características intrínsecas a estes seres e cidades próprias, é necessário, para articular essas camadas, perceber primeiramente a "invenção do cotidiano" feita por seus atores que, segundo Duran, "[...] se dá graças ao que Certeau chama de 'artes de fazer', 'astúcias sutis', 'táticas de resistência' que vão alterando os objetos e os códigos, e estabelecendo uma (re)apropriação do espaço e do uso ao jeito de cada um" (2007, p.119). Assim, essa invenção será investigada ao buscar-se a compreensão dos coautores que compõem cada camada (e que podem ser parte de várias delas), suas territorialidades definidas, bem como as micropolíticas que as envolvem e o papel de seus corpos.

\section{Conceitos}

\section{Territorialidade}

A compreensão da territorialização das ações das camadas coautoras de cidade, das práticas do espaço e da construção do cotidiano são imprescindíveis para o aprofundamento do tema. Afinal, estas camadas não estão "livres" de um contexto e esse contexto é moldado pelas mesmas. Ou seja, as complexas relações entre cultura, desejo e corpo são raiz para o entendimento do conteúdo interno de cada ser, que é externalizado e disseminado em meio/para a cidade e para outros seres.

Para explicar sobre territorialidade, Guattari e Rolnik (2013) colocam que "os seres existentes se organizam segundo territórios que os delimitam e os articulam aos outros existentes e aos fluxos cósmicos". Eles apontam que o território não se atém ao espaço físico, podendo ser "[...] relativo tanto a um espaço vivido, quanto a um sistema percebido no seio do qual um sujeito se sente 'em casa'. O território é sinônimo de apropriação, de subjetivação fechada sobre si mesma" (GUATTARI e ROLNIK, 2013, p. 388). Assim, para investigar sobre as cidades construídas pelas camadas coautoras, é necessário compreender quais relações com o espaço físico elas têm, 
somado às relações entre as suas subjetividades e o sistema daquele local. E ainda deve-se entender sobre desterritorialização, pois muitas destas ações, no caso, das camadas do urbanismo de base, podem ser temporárias, como será colocado adiante. Segundo Guattari e Rolnik (2013), há um "imenso movimento de desterritorialização, no sentido de que seus territórios 'originais' se desfazem ininterruptamente com a divisão social do trabalho [...]" (p. 388), dentre outras coisas, o que torna fundamental compreender que os diferentes papéis empenhados pelas camadas podem entrar em conflito, gerando constantes desterritorializações.

\section{Micropolítica}

O território também envolve as pessoas que por ali habitam, circulam e interagem de alguma forma, o que leva ao estudo das micropolíticas que envolvem a coautoria de cada camada. Segundo Guattari e Rolnik (2013), a micropolítica é " [...] a questão de uma analítica das formações do desejo no campo social - diz respeito ao modo como o nível das diferenças sociais mais amplas [...]" (grifo dos autores, p. 149). Compreende-se que a micropolítica articula os desejos refletidos por cada subjetividade dos coautores, sejam eles de base ou de topo, pertencentes ao contexto original ou não. Assim, cada ação deve ser parte de um processo que busca o equilíbrio entre estes desejos, entendendo que a garantia desta micropolítica em processo "[...] só pode - e deve - ser encontrada a cada passo, a partir dos agenciamentos que a constituem, na invenção de modos de referência, de modos de práxis [...]" (GUATTARI e ROLNIK, 2013, p. 38).

\section{Corpos, subjetividades e papéis particulares}

Segundo Guattari e Rolnik (2013), "a questão micropolítica é a de como reproduzimos (ou não) os modos de subjetivação dominantes" (p. 155). Portanto, as micropolíticas e desejos refletem as subjetividades e as diferentes perspectivas que permeiam as pessoas e os grupos que vivem a cidade, entendendo que cada um carrega diferentes noções do que é o corpo. Dessa forma, "o corpo, o rosto, a maneira de se comportar em cada detalhe dos movimentos de inserção social é sempre algo que tem a ver com o modo de inserção na subjetividade dominante" (GUATTARI e ROLNIK, 2013, p. 336). Esse domínio modifica as formas de apropriação dos coautores, pois cada um tem níveis diferentes de liberdade para usufruir da cidade, geralmente construída pela definição e pela aparência de seu corpo. Nenhum corpo é puro, nem o recém nascido. Em todos existem marcas e atravessamentos que também fomentam a produção de suas subjetividades, o que pode gerar o conflito entre o afloramento delas e a prisão seletiva promovida pelo poder, que as priva da liberdade de externalizar seus anseios ao ocupar a cidade. Por isso, cada coautor torna-se responsável por um ou vários papéis, que podem ir se transformando ao longo de diferentes territórios e tempos. Esses papéis devem afirmar-se e fazerem-se vivos, segundo Guattari e Rolnik (2013), de forma que resistam às tentativas de nivelação das subjetividades. Se essa resistência levar a uma liberdade de seus corpos e das subjetividades, a leitura sobre a realidade torna-se mais clara e "essa capacidade é que vai lhes dar um mínimo de possibilidade de criação e permitir preservar exatamente esse caráter de autonomia tão importante" (GUATTARI e ROLNIK, 2013, p. 55). 
Por não existir corpo homogêneo universal, serão trabalhadas a seguir as diferenças. Cada cidadão carrega em si a difusão de subjetividade, experiência e cultura. Para entender essa experiência, é preciso compreender a inseparabilidade da teoria e da práxis social, que "[...] é algo que se busca no próprio movimento, incluindo-se aí os recursos, as reapreciações e as reorganizações das referências que forem necessários" (GUATTARI, 2013, p. 34).

\section{As camadas}

Holston (1996) explica que, segundo T.H. Marshall, "a cidadania é um status conferido a quem é membro pleno de uma comunidade. Todos os que o possuem são iguais em relação aos direitos e deveres que a esse status são atribuídos" (grifo do autor, p. 250). Todos são cidadãos, ou, seguindo essa definição, deveriam ser considerados. Entretanto, sabe-se que os direitos e deveres se perdem em meio à tantos fatores que interferem na vida urbana, de forma que fiquem desequilibrados. Esse desequilíbrio é, sem dúvidas, simbiótico, onde quanto mais direitos alguns tem, menos outros tem, fazendo com que menos deveres se cumpram também por falta de recursos que deveriam ser concedidos por direito. Assim, a cidadania pode ser também seletiva, e há uma luta para que ela seja de todos. A seguir, será trabalhado de forma mais genérica sobre os coautores do urbanismo de topo, uma vez que serão priorizadas as camadas do urbanismo de base. Serão aprofundadas três camadas de cidadãos, onde a terceira não carrega este título, mas recebe a palavra "urbano", que deixa clara a relação de ação na cidade.

\section{Coautores do urbanismo de topo}

O urbanismo de topo é praticado por camadas que detém algum poder, cujos atores geralmente pertencem às classes dominantes. As atuações destas classes, segundo Holston (1996), "[...] contrapõem-se aos avanços dos novos cidadãos com novas estratégias de segregação, privatização e fortificação. Apesar de a cidade ter sido sempre um lugar para tais contestações, elas assumiram formas novas e particularmente intensas nessas últimas décadas" (p. 251). Estes coautores são responsáveis pela construção das cidades-imagem, sendo elas o espetáculo não vivido e sim apresentado, onde uma falsa realidade é colocada, sendo "[...] obra com sua autoria concentrada em poucos, onde não há consideração sobre para quem foi feita e sim contemplação vazia" (ROCHA, 2018). Estas cidades podem ser responsáveis pelo impedimento do uso dos espaços por corpos menos favorecidos, por exemplo, e podem também tornar a percepção de poder deles embaçada, fazendo com que não enxerguem a potência de suas atuações, especialmente em conjunto.

Esta camada geralmente é constituída por governantes nas mais diversas posições, empresários, empreiteiros, entre outros. Estes atores citados geralmente possuem laços e alianças, onde um apoia o outro e o capital excedente do governo é injetado em obras urbanísticas feitas pelas mesmas construtoras, mediada por empresários, etc. Além destes atores, outros são parte do urbanismo de topo, onde inclusive o próprio urbanista pode ter participação. Jacobs (2011) comenta sobre o papel deste ator que, quando alinhado ao poder e aos recursos federais, tem "[...] plenas condições de destruir as misturas de usos principais urbanas mais rápido do que elas conseguem florescer nos bairros espontâneos, de modo que o resultado é a perda da mescla principal básica" (p. 195). Esta postura é contrária ao que entende-se como uma 
Figura 2: Urbanismo de topo: as ruínas da Vila Autódromo contrastam com os edifícios em construção para os jogos olímpicos. Fonte: Autora, 2015. "boa" cidade, pois usa de favorecimentos lucrativos (ou necessidade) colocando-os superiores à produção democrática e abrangente de usos da cidade.

Os projetos urbanísticos historicamente interviram de forma elitista na cidade, como nos casos dos planos Haussmann em Paris ou mesmo no "bota-abaixo" de Pereira Passos no Rio de Janeiro. Na visão dos urbanistas, esta cidade imposta pode ser interessante, mesmo que não considere de forma primordial os próprios cidadãos. Afinal, foi implementada, de certa forma, por eles mesmos em parceria com outros atores. Sabe-se que é muito comum quem pense nos usos e nas articulações na cidade não ser usuário delas, como por exemplo na organização do transporte público. É uma criação distante e limitada a uma bolha, onde o criador admira a sua criação e tem certeza de sua plenitude. Entretanto, é tempo (sempre foi) dos urbanistas quebrarem o muro invisível que os separa dos espaços que vão intervir, considerando os variados usos e apropriações do espaço público na cidade, e as práticas insurgentes, que serão tratadas a seguir.

\section{Coautores do urbanismo de base}

As práticas insurgentes na cidade revelam pequenos pontos quentes e vivos, pensados e materializados de alguma forma pelos cidadãos, em meio a uma frieza e a uma rigidez urbana. Os espaços aflorados pelas "[...] cidadanias insurgentes constituem novas formas metropolitanas do social ainda não absorvidas nas velhas, nem por elas liquidadas" (HOLSTON, 1996, p. 244). Assim, as camadas coautoras do urbanismo de base são formadas exatamente por estes cidadãos que, de alguma forma, causam alguma transformação na cidade.

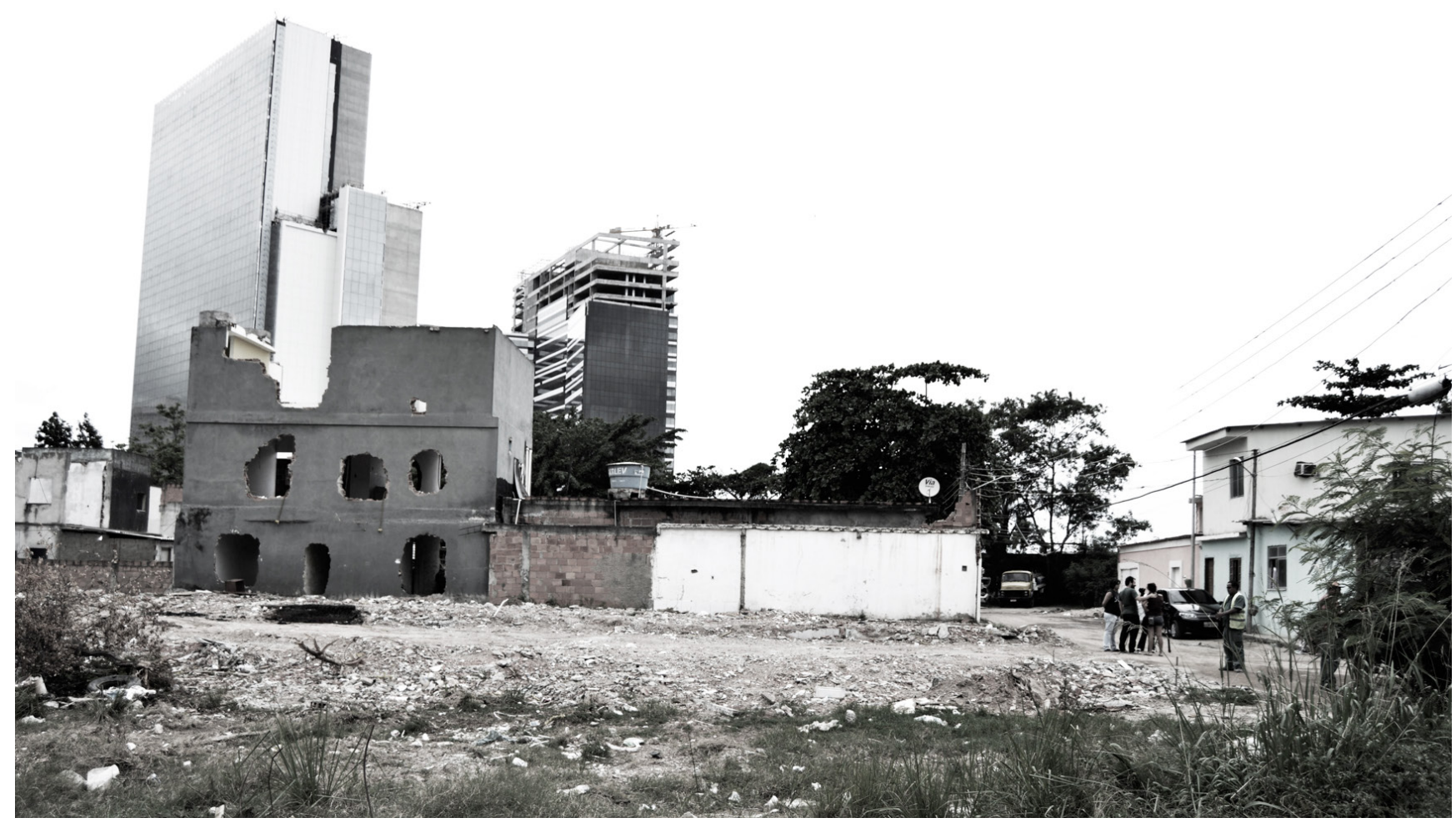


Os lugares de insurgência "[...] introduzem na cidade novas identidades e práticas que perturbam histórias estabelecidas. Essas novas identidades e as perturbações que elas causam podem ser de qualquer grupo os classe social" (HOLSTON, 1996, p. 250). Ou seja, são abrangentes as formas de coautoria urbana, desde escala até classe, o que revelou a existência de algumas camadas coautoras, compreendendo atores que podem pertencer a mais de uma delas. A seguir, serão tratadas três destas camadas coautoras: os cidadãos formais, os cidadãos marginalizados e os ativistas urbanos.

Nem sempre estas camadas têm suas ações planejadas como forma de subversão de um uso, reivindicação ou resistência. Holston (2014) pontua que não é necessário que ocorra somente esta organização pensada pelas camadas de base para que suas ações/práticas insurgentes aconteçam, transformando o meio urbano. Estas práticas podem acontecer "[...] em práticas cotidianas que, de diferentes maneiras, legitimam, parodiam, desordenam ou subvertem as agendas do estado" (HOLSTON, 2014, p. 249). Por isso, dentre as três camadas que serão desenvolvidas adiante, uma delas é constituída pelo chamado "cidadão formal", que pode causar subversão sem uma ação planejada para tal, como pode fazer, por exemplo, o "ativista urbano".

A prática coautora insurgente pode acontecer com ou sem planejamento, de forma que os corpos destes cidadãos explorem os espaços livremente, subvertendo os usos pré-definidos, impondo e inscrevendo também ali a marca de sua autoria. Velloso (2017) explica que, em uma insurreição, têm-se "[...] corpos trafegando pelos lugares, corpos experimentando espaços desviados de suas funções primárias, em usos corpóreos dos lugares que não raro são extrapolações de atribuição programática (ou funcional), de um lugar [...]" (p. 45). Assim, têm-se corpos que são livres ou que buscam a liberdade a partir de suas ações.

Devido à abrangência das ações das camadas do urbanismo de base, elas também podem atuar como uma forma de chamar a atenção das camadas detentoras de poder do urbanismo de topo, previamente a ação destas sobre a cidade. Dessa forma, podem ganhar apoio, tornando reais os desejos dos cidadãos através de ideias que partam deles mesmos. Assim, segundo Holston (1996), os objetivos teóricos referentes às formas insurgentes do social visam "[...] entender a sociedade como uma contínua reinvenção do social [...]. Os planejadores precisam se lançar à procura das fontes emergentes de cidadania - e sua repressão - que indicam essa invenção" (p. 250). Portanto, a seguir, serão discutidas as visões de diferentes autores sobre a coautoria urbana, de forma articulada, e organizadas nas três camadas, como forma de estudo que amplie um trecho microscópico das noções de uso da cidade por parte dos cidadãos mais diversos.

\section{Cidadãos formais}

Há um tom de alerta quanto Velho (2007) escreve que "[...] a familiaridade não é sinônimo de conhecimento, e que estranhar o familiar é um movimento necessário para buscar compreender os mundos sociais por onde circulamos, convivemos e interagimos" (VELHO, 2007, p. 13). O cotidiano traz por diversas vezes certo acomodamento - a tal familiaridade - ou mesmo relações mais objetivas com metas e desejos a serem cumpridos, fazendo com que a expansão do conhecimento e do questionamento aconteçam em menor grau. Estes coautores são os que usam do espaço da cidade 
2 Privilegiados no sentido de não sofrerem impactos negativos diretos com as modificações urbanas.

Figura 3: O banco utilizado conforme seu uso original na Praça Marechal Âncora. Fonte: Autora, 2016. como local de circulação ou de espera, podem aproveitar os serviços ofertados pelas ruas e também são os que usufruem dela para lazer. A acomodação do cotidiano e a inserção geralmente dentro de grupos privilegiados ${ }^{2}$ torna quase inexistente o questionamento sobre a imposição de certos usos e modificações na cidade. Assim, a familiaridade pode tornar estes corpos e mentes passivos às diversas camadas e mundos que constroem o meio urbano.

Os laços com a rua são menos profundos a partir do momento em que a apropriação destes atores tem velocidade mais rápida ou é esporádica. Ao entender que "a confiança na rua forma-se com o tempo a partir de inúmeros pequenos contatos públicos nas calçadas" (JACOBS, 2011, p. 60), percebe-se que os laços tornam-se mais fortes quando pequenas conexões com outros espaços e pessoas tornam seus percursos mais lentos e mais atentos. Jacobs (2011) comenta a importância destes contatos proveitosos da convivência na rua, argumentando que, de certa forma, essa é uma das serventias da cidade e que, mesmo que aparentemente sem pretensão ou propósito, estes contatos podem gerar o afloramento de uma vida pública interessante na cidade.

Como exemplos de atores que pertencem a esta camada, encontra-se o funcionário ou trabalhador, a pessoa que sai para lazer, os moradores "formais", dentre outros, e salienta-se que todos podem pertencer à mais de uma camada dependendo da situação ou contexto em que estiver inserido. Ainda assim, percebe-se que estes atores são reconhecidos pelo sistema e fazem uso corriqueiro, desapercebido e/ou condicionado dos espaços. Gehl (2013) defende que estes usos podem ser atividades necessárias, que devem ser feitas e que acontecem sob todas as condições, ou atividades opcionais, que acontecem na maioria das vezes sob boas condições de cidade, "[...] sendo recreativas, das quais as pessoas poderiam gostar [...]" (GEHL, 2013, p.20).

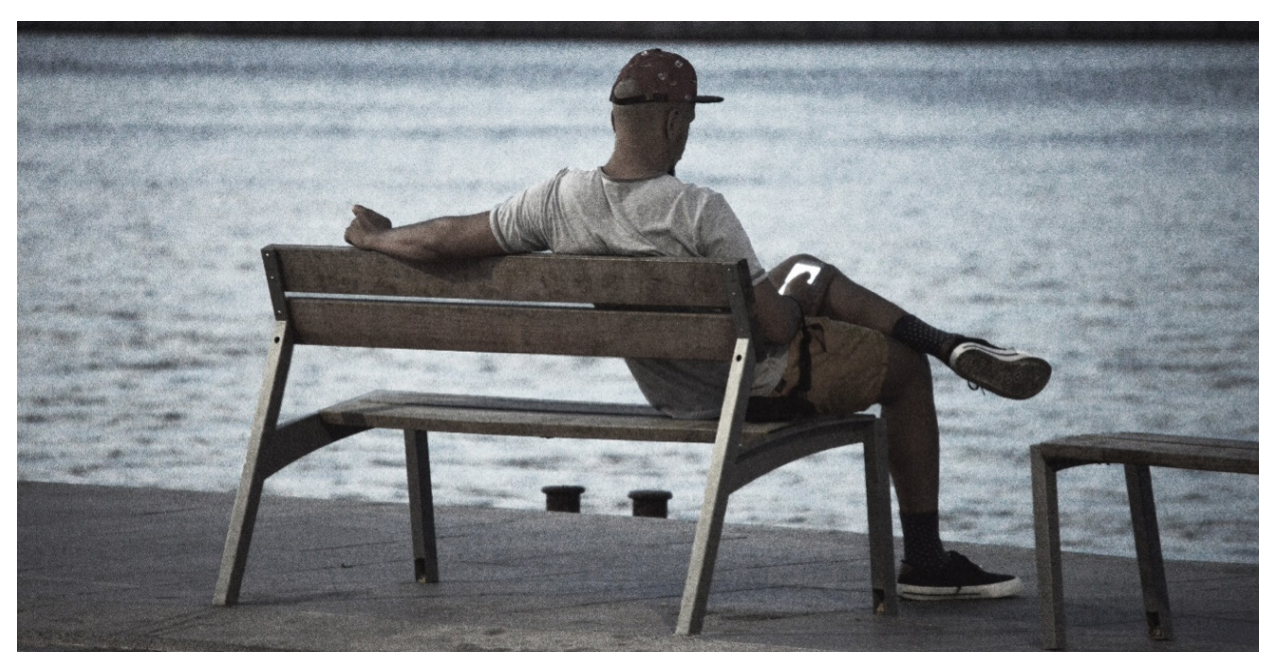


Figura 4: Ocupação inesperada: cadeiras de praia dispostas e utilizadas na Praça XV. Fonte: Autora, 2016.
Assim, os atores desta camada praticam atividades corriqueiras como, por exemplo, descer do ônibus e caminhar até o edifício onde trabalham sem perceber o que acontece neste caminho, fazendo com que obstáculos vencidos pelo corpo, como postes ou árvores, passem desapercebidos, assim como as lojas ou camelôs, tendo como único foco a chegada ao seu local de trabalho. Por outro lado, estes atores podem reconhecer o espaço urbano que percorrem, os elementos presentes em seu caminho, reconhecer que a calçada em determinado local deveria ser maior, que árvores tornariam mais agradável, etc. Jacobs (2011) escreve que "a calçada por si só não é nada. É uma abstração. Ela só significa alguma coisa junto com os edifícios e os outros usos limítrofes a ela ou a calçadas próximas. Pode-se dizer o mesmo das ruas, no sentido de servirem a outros fins, além de suportar o trânsito sobre rodas em seu leito" (p. 29). Assim, apesar do uso corriqueiro e formal, estes coautores somam e fomentam novos significados às calçadas e às ruas, tornando-se, também, parte imprescindível para a construção de uma cidade viva e interessante.

Já a prática de atividades opcionais, atrativas e populares depende de uma boa qualidade urbana (GEHL, 2013). Se há qualidade, estes atores são os que possuem maior liberdade para usufruir do espaço. Entretanto, Careri (2013) aponta que o próprio caminhar pode aumentar a qualidade espacial, sendo "[...] um instrumento estético capaz de descrever e modificar os espaços metropolitanos que muitas vezes apresentam uma natureza que deve ser compreendida e preenchida de significados, antes que projetada e preenchida de coisas" (grifo do autor, p. 32). Os fluxos geram novos significados nos espaços percorridos, muitas vezes estimulando a própria ocupação por parte dos atores de outras camadas, ou seja, estimulando o posterior preenchimento do físico do espaço.

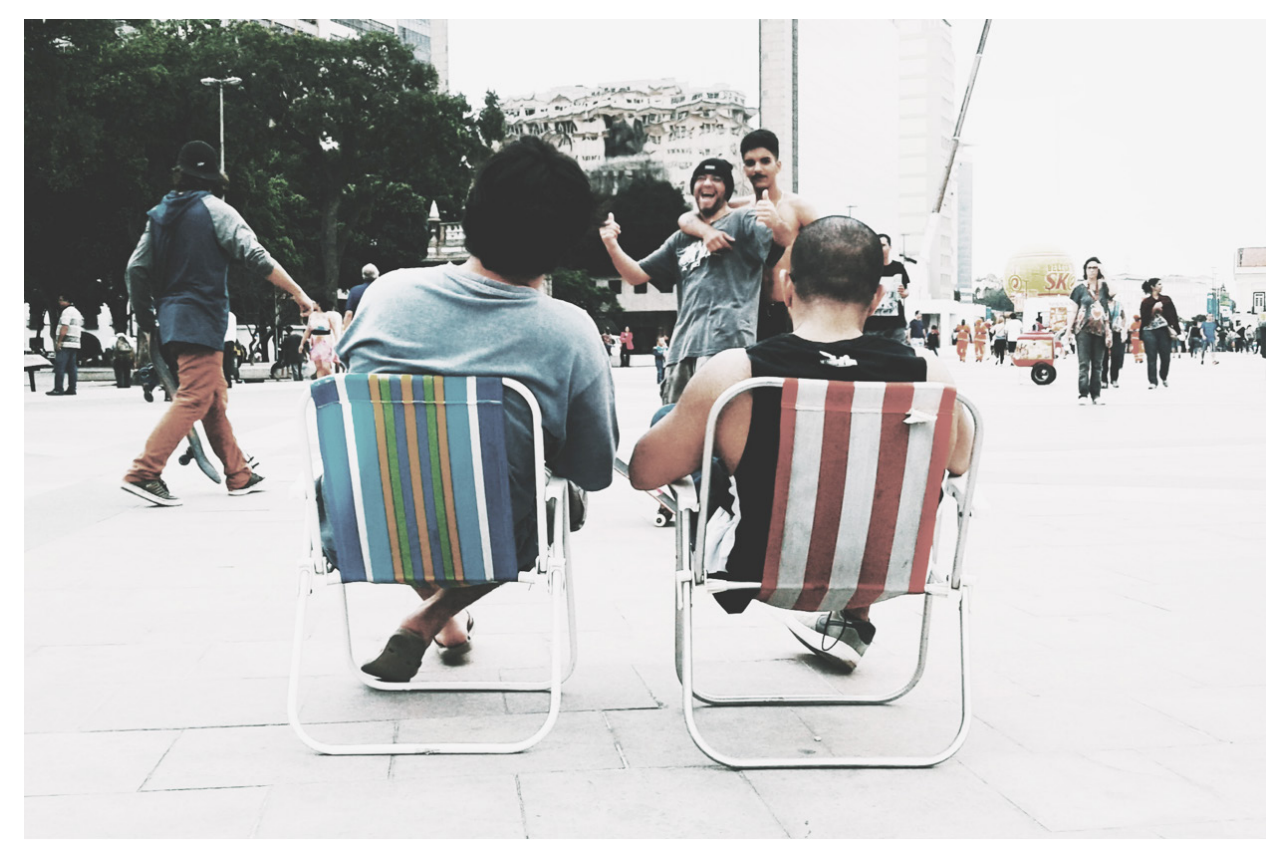


Figura 5: A cidade como espaço de circulação. Fonte: Autora, 2016.
3 Tradução livre do trecho "[...] esa especie de 'facultad de arquitectura del malandraje' [...], donde se va aprendiendo una forma de vivir tratando de 'no jorderse', a través de la coexistencia de cosas antagónicas".

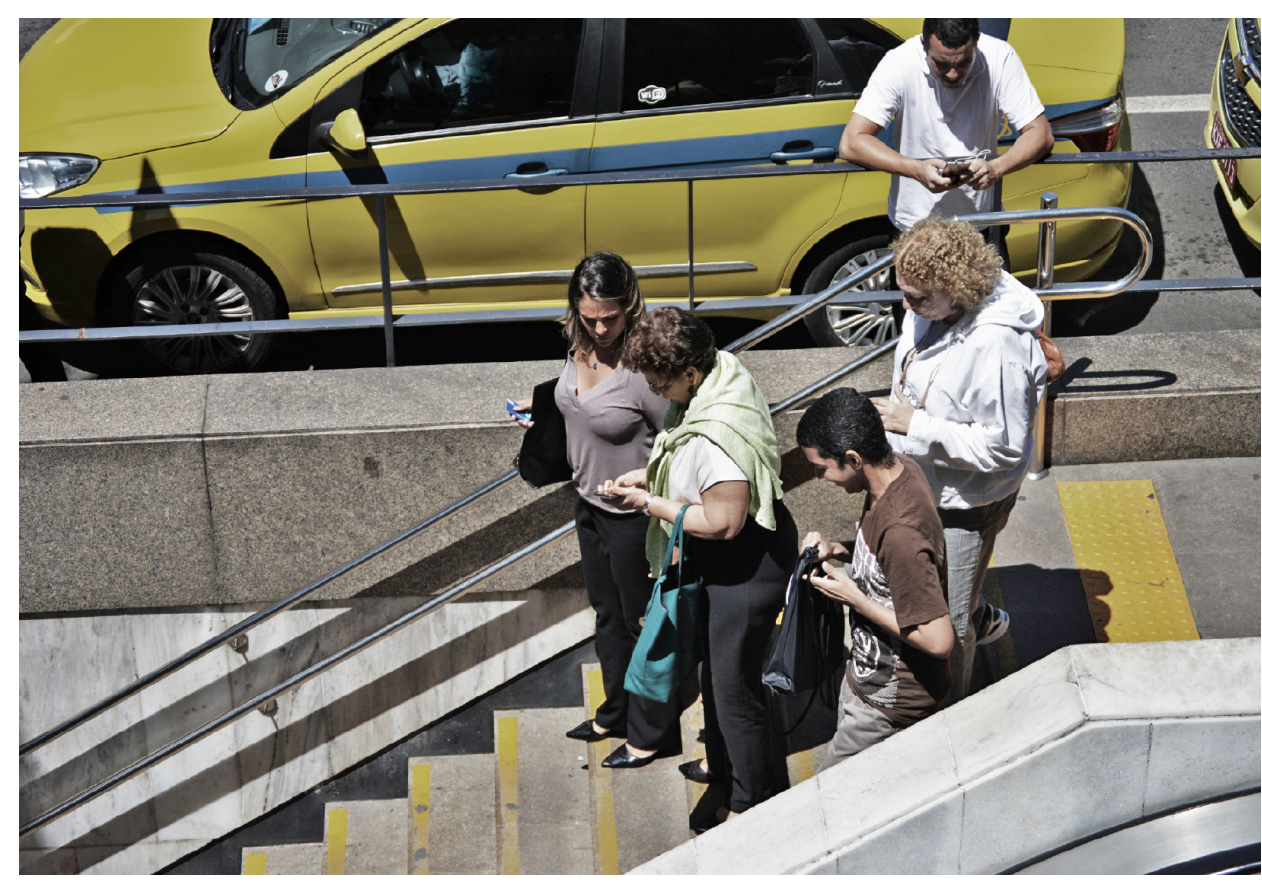

Estes atores também podem apropriar-se do espaço de forma esperada (por exemplo, ao utilizarem o banco da praça como local de estar), não esperada (por exemplo, ao aguardarem o ônibus em um ponto sem infraestrutura e sentarem-se em um balizador de concreto que possui outra finalidade), ou ainda não apropriar-se.

Nesta camada, a cidade é espaço de lazer, de circulação, de serviço e de espera.

\section{Cidadãos marginalizados}

Velloso (2017) pontua a falha na previsão das práticas oposicionistas por parte dos projetos urbanos, onde "[...] as classes trabalhadoras, as classes perigosas, os operários e os pobres se apropriaram do espaço onde estavam subjugados e marcaram sua geografia [...]" (p. 62). Ao listar estas classes/atores, Velloso introduz a ideia do que seria esta coautoria por parte dos cidadãos marginalizados, que são os que fazem uso dos espaços públicos pela necessidade de viver e sobreviver, onde a rua torna-se "[...] essa espécie de 'faculdade de arquitetura da malandragem' [...], onde se aprende uma forma de viver tentando 'não importar-se', através da coexistência de coisas antagônicas" ${ }^{3}$ (JÁUREGUI, 2008, p. 186). Entretanto, o antagonismo fomenta o clima de guerra entre as diferentes camadas da cidade, o que ameaça, segundo Holston (1996), a formalidade universal, levando a uma dificuldade na administração de tantas identidades sociais simultâneas. O antagonismo, então, potencializa a marginalização de certos cidadãos em suas atuações no meio urbano.

Estes cidadãos, portanto, são corpos em branco na cidade, invisibilizados e, como colocam Guattari e Rolnik (2013), as chamadas "pessoas-margens" ou marginais são 
4 Tradução livre do trecho "[...] dialéctica entre el orden y el desorden, y la capacidad de indeterminar las cosas, de confundirlas. Implica una sabiduría del esquivarse, que es también lo esencial del 'malandraje'".

Figura 6: Ambulantes durante evento na Praça Marechal Âncora. Fonte: Autora, 2016.
"[...] as vítimas de uma segregação e são cada vez mais controladas, vigiadas, assistidas nas sociedades [...]" (p. 143). Os autores também comentam que "[...] tudo o que não entra nas normas dominantes é enquadrado" (p. 143). O não enquadramento compreende uma forte resistência, não só em prol da subjetividade de cada corpo mas, nesse caso, especialmente pela necessidade de sobreviver em meio à cidade, carregando grande potência e criatividade em suas formas de ocupação. Assim, o cidadão marginalizado é obrigado a incorporar o espaço em si e a ser incorporado por ele, enxergando na cidade infinitas possibilidades em cada brecha ou microespaço. Esta marginalidade geralmente é, então, associada à informalidade, implicando em uma "[...] dialética entre a ordem e a desordem, e a capacidade de indeterminar as coisas, de confundi-las. Isso implica uma sabedoria de esquiva, que também é o essencial da 'malandragem'" 4 (JÁUREGUI, 2008, p. 186).

As experiências por parte dos cidadãos marginalizados geram o que Jacques (2009) chama de corpografias urbanas de resistência, que mostram através das pequenas práticas do dia a dia e das "[...] apropriações diversas do espaço urbano que não são percebidas pela maioria dos estudos urbanos mais tradicionais [...]" (p. 137), o que é desconsiderado pelos projetos urbanos implementados pelo espetáculo. Estas pequenas práticas também são consideradas pequenas insurgências em meio ao espaço da cidade.

Ao escrever sobre as impressões de Benjamin e sua presença na história urbana, Velloso (2017) desenvolve sobre as insurreições e as cicatrizes da cidade, comentando que as insurgências são rupturas e cada uma delas "[...] instabiliza os hieróglifos espaciais [...]. Toda e cada insurgência explode a lógica subjacente ao urbano desenhado e planejado" (p. 45). Assim, as insurgências são explosões que lançam fragmentos sobre

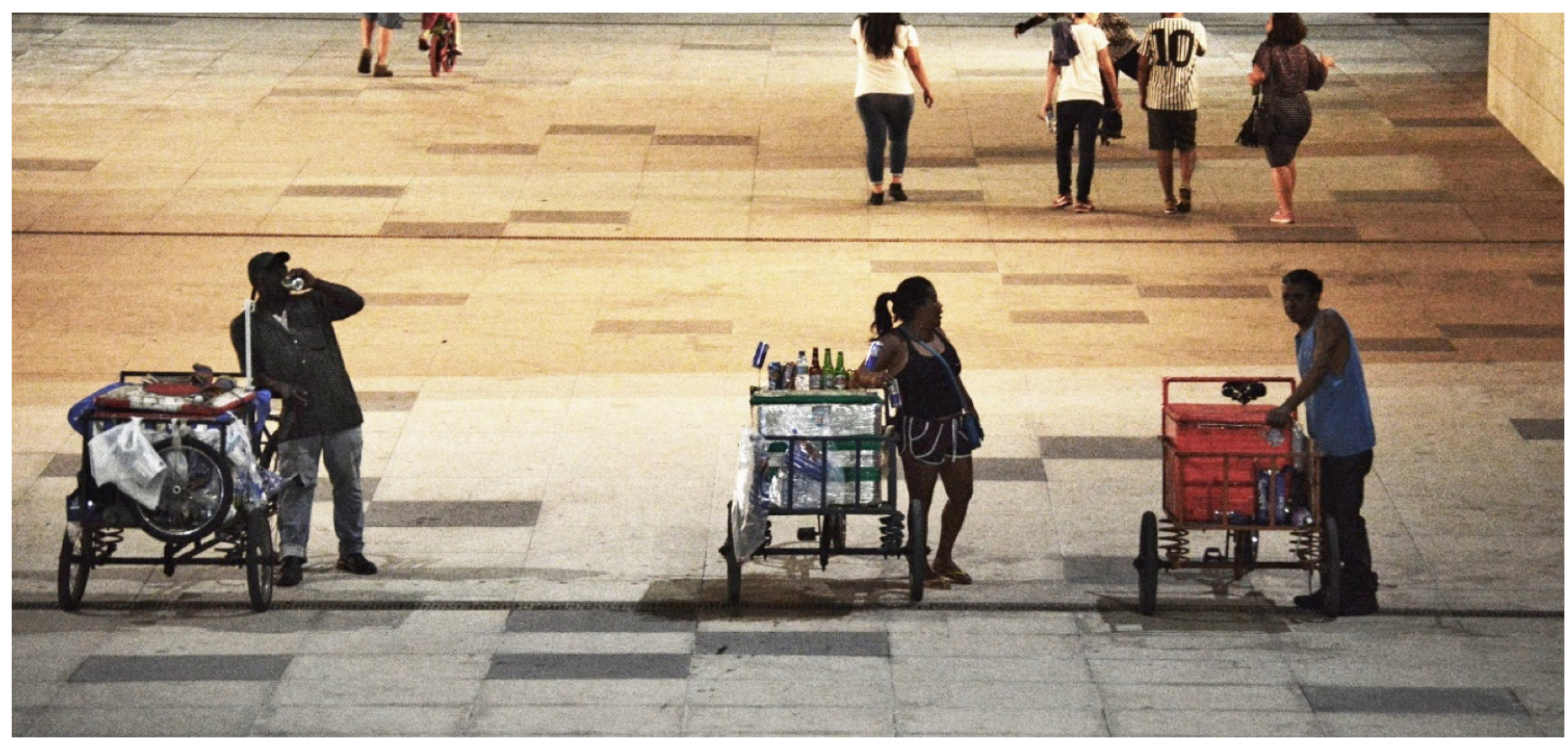


Figua 7: Praça-casa: O banco tendo seu uso original subvertido na Praça Mauá. Fonte: Autora, 2018.

\footnotetext{
5 Tradução livre do trecho "[...] es en este sentido, de aguzar el potencial de imaginación para la utilización de los medios materiales y humanos, que la vida en la informalidad tiene algo de muy positivo. Aguzar nuestra percepción para la singularidad de cada situación en la perspectiva de su articulación al circuito de la interconexión y la información, revelando potenciales".
}

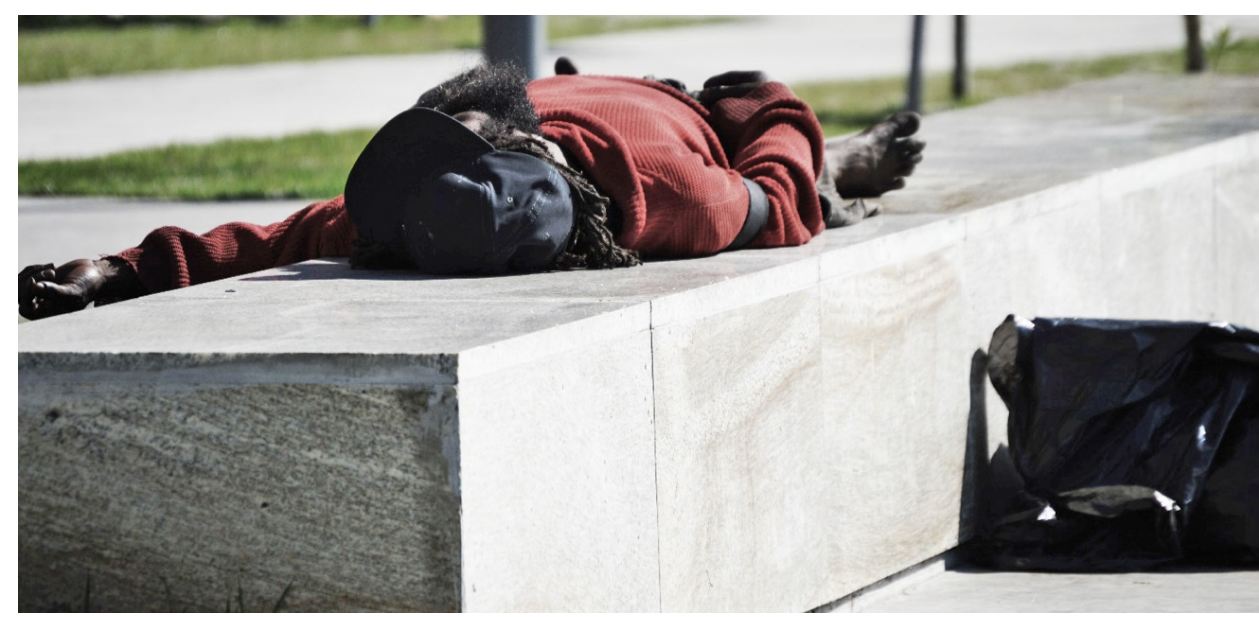

o que está em volta, criando pequenos núcleos de transformação que são circundados por diversas camadas afetadas por sua vibração em níveis diferentes. Holston (1996) levanta a importância dessas insurgências para a reflexão projetual, onde deve-se contemplar o social, porque ela "[...] revela um domínio do possível que está enraizado na heterogeneidade da experiência vivida, isto é, no presente etnográfico e não em futuros utópicos" (p. 252).

Certeau (2014) traz então a questão sobre a fronteira, questionando a quem ela pertence. Segundo o autor, a fronteira tem um papel mediador, funcionando como um "entre dois", e é exatamente sua quebra que gera, também, a marginalização destes cidadãos, pois eles geralmente apropriam-se de forma inesperada da cidade, gerando novos usos e novas possibilidades ao espaço. Assim, há uma ruptura das fronteiras construídas pelo urbanismo de topo ou mesmo pela sociedade ao longo dos anos, de forma que gera-se o desconforto, especialmente entre os cidadãos formais.

Dentre os coautores que pertencem a esta camada, observa-se, por exemplo, a pessoa em situação de rua, o camelô, dentre outros, e salienta-se que todos podem estar em mais de uma. Um exemplo de cidade criada por esta camada de coautores seria o momento em que uma loja de móveis que não abre aos domingos receber nestes dias, em sua calçada, uma barraca montada por um camelô, delimitada pelos seus próprios produtos, que também são pendurados na porta fechada da loja. Ou mesmo uma pessoa que, sem ter um teto, dorme embaixo de uma marquise, pois é o local mais seguro para se estar, juntamente com outras pessoas. Jáuregui coloca que

[...] é nesse sentido, para aguçar o potencial da imaginação para o uso de meios materiais e humanos, que a vida na informalidade tem algo muito positivo. Aguçar nossa percepção pela singularidade de cada situação na perspectiva de sua articulação ao circuito de interconexão e informação, revelando potenciais". 5 (JÁUREGUI, 2008, p. 186) 
Figura 8: Criança participa da intervenção temporária "Casa da Mãe Santana", promovida pelo LabIT em parceria com o Instituto Tear no Campo de Santana. Fonte: Autora, 2017.
Os cidadãos marginalizados ainda carregam a maior prática da errância em meio a cidade, pois se sentem mais livres ou necessitados para tal. Devido ao seu desprendimento com relação às formalidades impostas, seus corpos que habitam/trabalham/subvertem o uso da cidade tornam-se grandes exploradores do que a maioria da população não explora, enxergando a prática do caminhar como possibilidade de conhecer e ser ainda mais parte do espaço urbano.

Nesta camada, a cidade é casa, é abrigo, é espaço de trabalho.

\section{Ativistas urbanos}

Holston (1996) levanta a urgência na teoria do planejamento e da arquitetura de "[...] desenvolver uma imaginação social diferente [...] que [...] reinvente os compromissos ativistas do modernismo com a invenção da sociedade e com a construção do estado" (p. 244). Lima (2015) segue a mesma ideia quando escreve que "a ambiência programada, presente em diversos projetos urbanos contemporâneos - com interações e posições definidas e projeções estabelecidas para os sujeitos - , pode ser desfeita pela situação ativista (ou artística) interventora" (p. 44). As duas intenções unidas - imaginação e intervenção - começam a desenhar um pouco desta camada. Essa imaginação pode ser certamente estimulada através da observação e de uma atuação mais efetiva no meio urbano, exatamente como a promovida por ativistas urbanos (que obviamente também podem ser arquitetos, urbanistas e planejadores). Assim, os atores que pertencem a esta camada podem fazer uso reativador de algum espaço estático ou excludente, podem subverter, criticamente, o uso de algum espaço, ou podem fazer uso indicador, de forma que um espaço pouco conhecido ou pouco utilizado se torne visto. Ou seja, "a cidade, matéria e produto das trocas humanas, parece se encerrar aos poucos numa trajetória fechada e excludente, e contra isso é que se colocam as vozes dos coletivos organizados" (LIMA, 2014, p. 35). Como forma de tornar clara a visão de quem são, de fato, os atores pertencentes à camada ativista urbana, listam-se alguns exemplos, como os artistas (individuais ou de coletivos), os produtores culturais, os arquitetos e urbanistas, os artistas de rua, dentre outros.

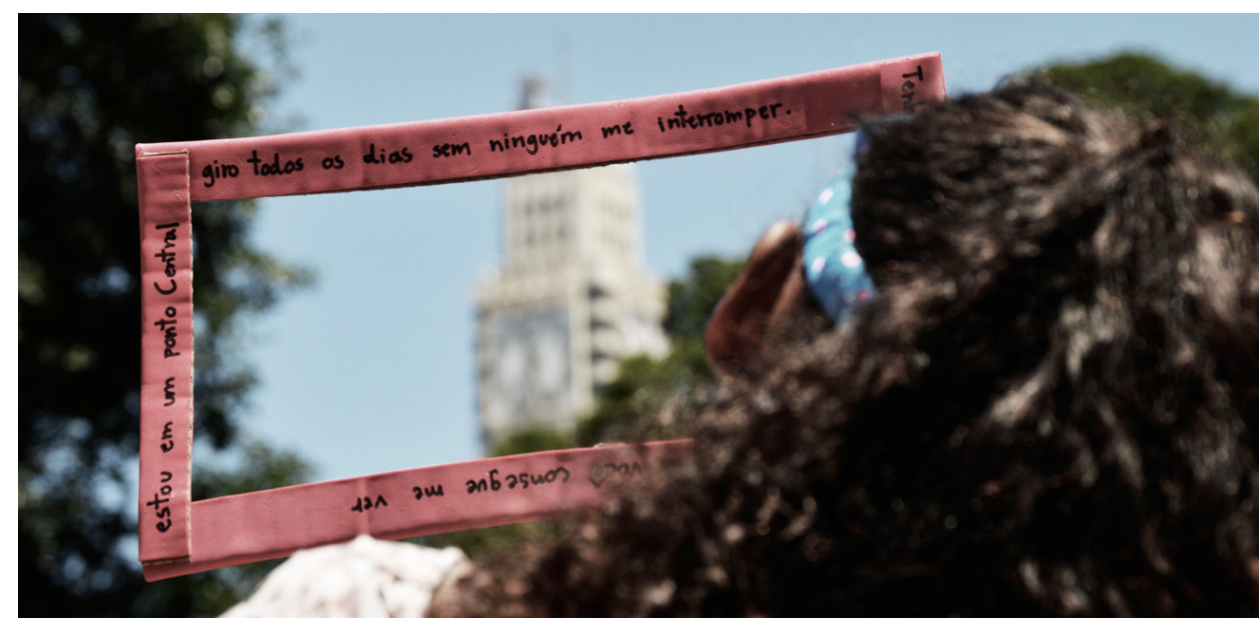


Belas praças pouco conhecidas ou pouco utilizadas recebem festivais pensados e organizados por estes atores, muitas vezes unindo os cidadãos formais e os cidadãos marginalizados, "[...] vozes que se colocam contra modelos de cidade pouco abrangentes e inclusivos [...]" (LIMA, 2015, p. 45), promovendo sua coexistência e respeito, onde a "[...] pluralidade de vozes demanda não apenas que o urbanismo se vincule a aspectos materiais, normativos e jurídicos, mas que incorpore em sua estrutura de projeto e planejamento as nuances reveladas pelos diversos movimentos que ecoam na cidade" (LIMA, 2015, p. 47). Também são coautores que podem propor apropriações e/ou apropriar-se do espaço de forma esperada ou inesperada. Ruas que recebem espaços de estar, vagas de carro sendo ocupadas por pessoas, a calçada que vira um palco de shows, todas subversões de uso do espaço promovidas por estes coautores. Lima coloca que "a ação solidária de grupos de indivíduos é um elemento articulador decisivo na dimensão urbana, devendo ser considerado não apenas nas contradições que revela, mas naquilo que possui de força propositiva" (LIMA, 2014, p. 34). A ocupação do espaço público promovida por ativistas urbanos, se temporária, é feita, assim, intencionalmente, não constando em um uso cotidiano do espaço. Entretanto, se for frequente sua ocorrência, gerando usos corriqueiros na cidade, sua marca na memória e o impacto no contexto podem fomentar mudanças cotidianas, modificando também a visão das pessoas sobre o local, e despertando suas respectivas consciências sobre o mesmo. Geralmente, a ocupação acontece em pequena escala pois, se tratando de camadas do urbanismo de base, é incongruente tratar de coautoria em larga escala, por ser o urbanismo com pouco ou nenhum recurso. Estas ocupações, portanto, podem ser compreendidas como pequenos pontos em meio ao grande corpo urbano.

A resistência e a produção de subjetividade, quando confrontadas pelo controle, geram a chamada "revolução molecular", segundo Guattari e Rolnik (2013). Estes movimentos sociais são "[...] não somente uma resistência contra esse processo geral de serialização da subjetividade, mas também a tentativa de produzir modos de subjetivação originais e singulares, processos de singularização subjetiva" (GUATTARI e ROLNIK, 2013, p. 54), o que elucida a luta, muitas vezes corporal, pelo afloramento de subjetividades reais, em contraposição à cidade que o capital impõe não só através do urbanismo de topo mas também quando se infiltra no urbanismo de base, serializando a subjetividade de forma disfarçada.

Por isso, apesar do domínio do comércio e da alimentação da mercantilização, segundo Harvey (2014), há de se aproveitar entre os produtores de cultura os pequenos grupos descontentes com esta imposição, o que as tornaria "[...] um campo fértil para a expressão crítica e a agitação política visando à produção de novos tipos comuns" ( $p$. 180). Este campo, então, é fertilizado pela insatisfação e pelo anseio por mudança, ou mesmo anseio por sentir o próprio corpo vivo e atuante de forma mais "nítida" no meio urbano. Estes grupos insatisfeitos e com interesses em comum formam grandes corpos vivos e enérgicos, que reconhecem e buscam alianças com seus pares ou aglutinam novos membros através de sua busca pelo conhecimento da cidade, formando constelações, como será colocado adiante. As barricadas em Paris exemplificam o quão relevante é a união e a apropriação por grupos de atores com desejos similares e, baseando-se em Benjamin, Velloso (2017) escreve sobre este tema, quando coloca que "a tomada dos lugares pelos habitantes decorre da familiaridade desses para com os lugares que, uma vez ocupados, são desfeitos, desmontados" (p. 51). A autora 
Figura 9: Moradoras observam a confecção da intervenção "Mapa-Muro", promovida pelo SOAR Estúdio na favela Rio das Pedras. Fonte: Evellyn Dias, 2018. explica também sobre como as barricadas, além de resistência, criaram redes entre as pessoas que se encaravam nelas todas os dias, unidas em uma mesma luta (p. 55), o que mostra o poder da formação de grupos com interesses em comum e disposição, fatores que somados, podem ser combustível na explosão de grandes subversões de uso e forma no meio urbano, especialmente partindo dos que conhecem, de fato, o espaço. Se, em suas lutas, somarem outros atores com algum tipo de poder financeiro que os apoiem, a facilidade da perpetuação das intervenções e atuações no meio urbano obviamente será facilitada. Entretanto, apesar da insatisfação com a atuação do capital poder ser o elemento que fertiliza as intervenções e ações no meio urbano por parte dos ativistas, a percepção dos agentes do capital frente ao sucesso destas intervenções pode fomentar sua própria mercantilização, o que deve ser observado com certa precaução, de forma que se evite o rompimento das conexões entre os pontos - ou pessoas/grupos - considerados dentro da esfera de uma ocupação/intervenção.

Pensando sobre estes pontos, Velloso (2018) escreve sobre o conceito de 'constelação' desenvolvido por Benjamin, entendendo as relações entre as estrelas que a compõem e as linhas imaginárias que se traçam entre elas, definidas também pelas distâncias entre estrelas e pela "[...] possibilidade de significado que o conjunto adquire, o sentido que lhe pode ser atribuído" (p. 101). Os ativistas podem formar constelações através de sua atuação, conectando atores locais e de outras regiões, além de profissionais dos mais diversos campos, formando linhas que podem tornar-se independentes dele mesmo a partir de um primeiro contato. Baseando-se na colocação de Velloso, entende-se que a atuação do ativista dá um significado diferente ao espaço através de uma grande rede de pequenos pontos luminosos interconectados. Velloso (2018), baseando-se na visão benjaminiana, escreve que "a constelação é uma imagem na qual cada estrela, um singular, marca um extremo de linha que a liga a outra estrela, outro extremo singular. Nesse traçado de linhas imaginárias que delimita uma forma,

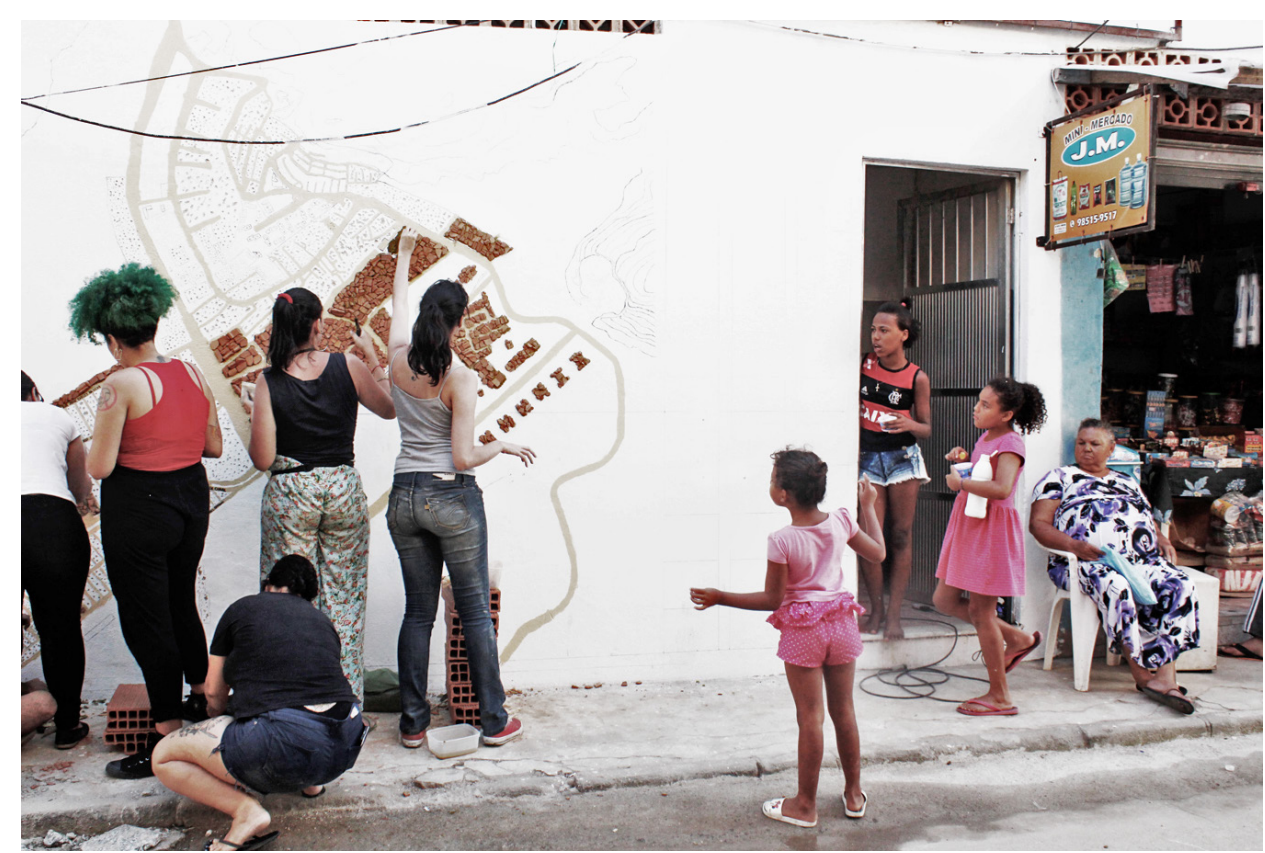


Figura 10: A peça Sorte ou Revés, promovida pelo Coletivo Peneira, ocupando e contando um pouco da história da Rua Joaquim Silva, na Lapa. Fonte: Autora, 2019.
6 Segundo Jacques (2009), corpografia urbana é a "cartografia realizada pelo e no corpo, ou seja, [...] parte da hipótese de que a experiência urbana fica inscrita, em diversas escalas de temporalidade, no próprio corpo daquele que a experimenta, e dessa forma também o define, mesmo que involuntariamente [...]" (p. 130).

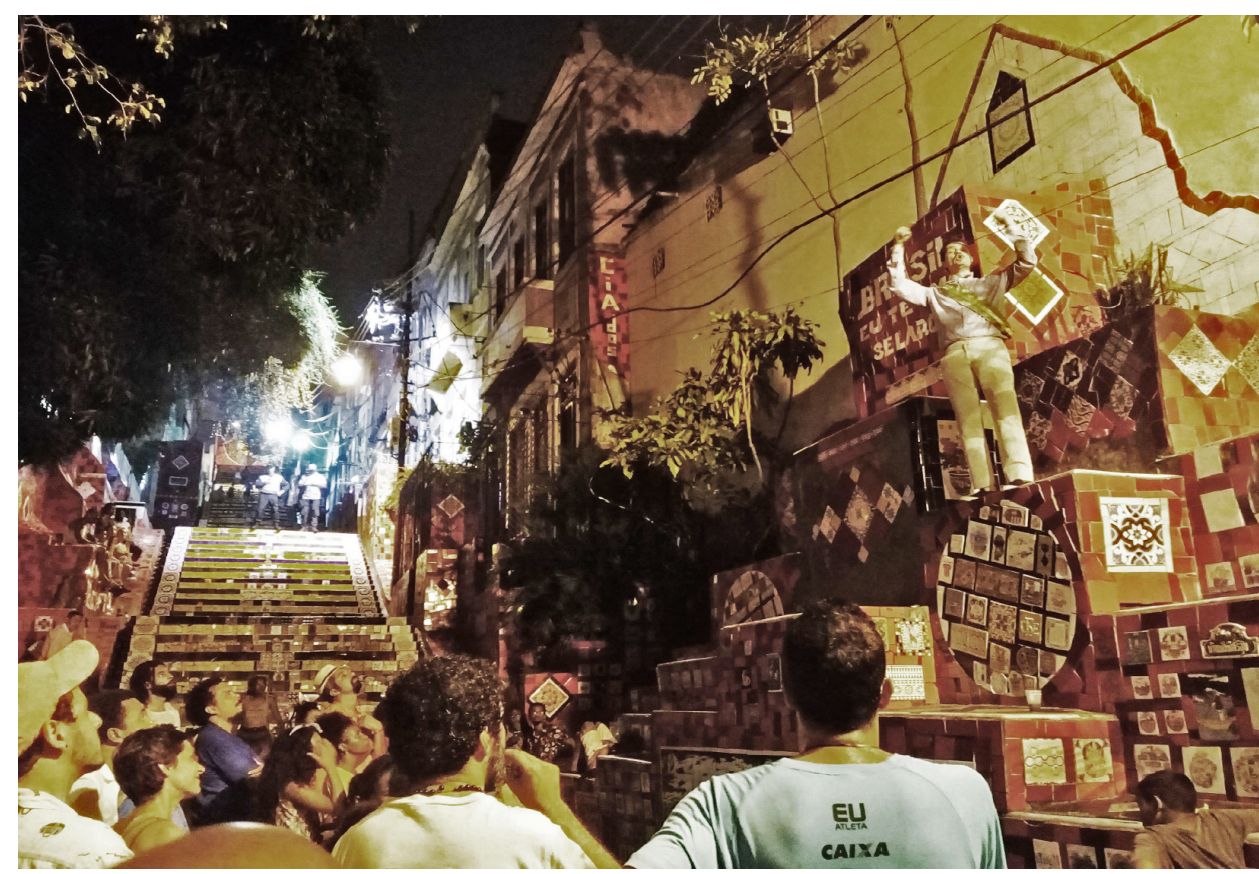

uma configuração, não há um centro [...]" (p. 102). Há uma importância dentro de cada ponto luminoso encontrado pelo ativista, e mesmo que ele seja o ponto que torna visível ou que constrói esta constelação, ele não é o centro pois não há um ponto central, e sim há uma grande possibilidade coletiva de iluminação e atuação no meio, carregando diferentes sentidos que dependem destes espaços a sofrerem intervenção antes de tornarem-se lugares.

Portanto, é, inteiramente importante a consideração sobre o local preciso a ser ativado e seus atributos físicos, que podem apoiar a ocupação ou mesmo elucidar novas ideias de fazê-lo. Sansão-Fontes (2013) levanta o valor destes atributos, pois cada intervenção vai ter uma relação própria com ele, fazendo com que "[...] ganhem relevo, reformatando os lugares e proporcionando um movimento cíclico positivo para sua sobrevivência: o espaço potencialmente atraente que se concretiza como um espaço amável estimulará sua reintervenção temporária e reinvenção permanente" (SANSÃO-FONTES, 2013, p. 388). Quanto mais precisa e detalhada for a observação e a consequente compreensão do local, mais este ciclo é alimentado, o que torna seu sucesso ainda mais efetivo. Esta ação obviamente gera novas situações no espaço, tornando-o lugar. Sansão-Fontes, citando Santos, explica como a ação no espaço faz com que ele ganhe estas novas características, ainda que mantenha algo de sua origem, de forma que seja "[...] como se a flecha do tempo se entortasse no contato com o lugar. O evento é, ao mesmo tempo, deformante e deformado" (SANTOS, 2008, p. 163 apud. SANSÃO-FONTES, 2013, p. 29). Portanto, conforme o lugar se modifica após as apropriações, ele vai gerar novas demandas por parte dos coautores ativistas, que aprimoram suas respectivas atuações atendendo estas novas necessidades. Consequentemente, as próprias pessoas têm seu comportamento naquele espaço modificado devido às novas corpografias ${ }^{6}$ que ele proporciona. Estas novas inscrições no corpo também são parte da alimentação da nova forma de intervir. 
Uma das principais consequências das ocupações no espaço público por parte dos ativistas é a chamada "amabilidade urbana" que, segundo Sansão-Fontes (2013), é "[...] a qualidade que surge da articulação entre as características físicas do lugar, as intervenções temporárias que ocorrem sobre este espaço e as pessoas que o utilizam e se conectam, demonstrando que a mesma surge da articulação entre as dimensões física, temporal e social" (p. 35). Sansão-Fontes (2013) também menciona sobre como a intervenção é um ponto que promove a interação com as pessoas e entre elas mesmas, "[...] aproximando-as, vitalizando os espaços e originando um novo ciclo que se autoalimenta, pois a amabilidade urbana pode permitir novas intervenções, que vão gerar espaços cada vez mais amáveis, e assim sucessivamente" (p. 32). Completando a colocação da autora, acredita-se que não só as intervenções temporárias como também as permanentes podem alimentar a amabilidade, conceito este tão necessário a uma sociedade anestesiada pelo individualismo, tanto com relação aos outros indivíduos quanto com relação ao próprio espaço da cidade. A conexão do corpo (física) e da mente (espiritual) com o meio urbano sólido (a pedra, como as edificações e calçadas) e com o meio urbano fluido (a carne, os outros seres) pode voltar a acontecer ou começar a acontecer a partir do momento em que a amabilidade urbana surge, consequente das intervenções. Esta forma de conexão é uma sensação que pode aguçar os sentidos do corpo que da cidade apropria-se, trazendo vida até mesmo ao que é estático em teoria, como por exemplo uma edificação ou uma calçada.

Sobre outros legados das intervenções, Sansão-Fontes (2013) defende que sua maior parte "[...] é construída no tempo, ou seja, a repetição da intervenção ao longo dos anos vai, pouco a pouco, transformando permanentemente o lugar" (p. 386). É algo lógico que pode ser associado a alguma habilidade, por exemplo, que quanto mais recebe investimento de tempo e prática, mais aprimorada e interessante se torna, e então mais se tem o desejo de evoluir. A repetição da intervenção aprimora o lugar e o torna cada vez melhor. Como complemento, após a análise de certo número de intervenções temporárias, Sansão-Fontes conclui que, mesmo intervenções que não apresentaram repetição "[...] contribuíram na construção de uma nova imagem do lugar, na descoberta do espaço para usos futuros ou em alguma valorização econômica" (p. 386). De certa forma, a colocação de Sansão-Fontes é confirmada após ler-se que, segundo Velloso (2017), cada ocupação/intervenção" [...] é um momento que talvez jamais integre uma série, mas é acontecimento em que se desvela uma possibilidade [...]" (p. 62). Ou seja, mesmo que seja uma ocorrência mínima e pontual, ainda assim pode ser munida de possibilidades enormes e que ecoam, dependendo da forma em que foi feita ou pensada pelo ativista e apropriada pelos cidadãos diversos.

Nesta camada, a cidade pode ser o que quiser ser.

\section{Conclusões}

Holston (1996) escreve que as diversas superfícies da cidade "[...] contam histórias e o tempo. As cidades estão cheias de histórias no tempo: umas, sedimentadas e catalogadas, outras, dispersas, em forma de rastros e vestígios. Suas narrativas são épicas e cotidianas [...]" (p. 243). Estas camadas são partes destas superfícies, especialmente as pouco catalogadas mas que são extremamente vistas e vividas, revolucionando o meio urbano em grande escala ou em microescala, com o próprio corpo, com instrumentos diversos ou mesmo com vários corpos. Em uma cidade como Rio de Janeiro, que vive de forma intensa o espaço da rua, é fundamental compreender as respostas às questões sobre territorialidade, micropolíticas, 
corpos e papéis que, articulados, geram o entendimento sobre essas camadas e seus conflitos, e sobre como estes podem gerar novas repressões. É necessário o conflito. É necessária a diferença. Holston (1996) defende que entender a multiplicidade é "[...] aprender a ler o social a contrapelo de suas formações típicas" (p. 253). Assim, há uma leitura ampla e fora do tradicional, de forma que se pensem as cidades compreendendo que as mesmas se transformam através destes seres que a habitam/constroem.

As múltiplas faces da coautoria mostram sua abrangência, de forma que todos são coautores em diferentes graus, podendo formar a cidade através de sua simples presença corpórea ou através da promoção de um evento, por exemplo. E a abrangência forma regiões tangenciais entre as camadas, onde, por exemplo, o ativista tenta construir uma liberdade para si, de forma que reflita nas diferentes camadas, com o intuito que todas tenham maior liberdade para práticas errantes, tudo através da sua ação no meio urbano. O cidadão formal, com sua presença, alimenta a construção de novos usos e serviços por onde circula, inclusive serviços dos cidadãos marginalizados, que também podem préocupar um lugar e fazer com que os "formais" tenham interesse em passar por ali ou não. Ou seja, as camadas não só se apoiam como devem sempre interagir, criar comuns entre elas, construindo estruturas que sirvam e se adequem a todas, entendendo-se que em suas atuações, não interessa uma conclusão ou um fim e sim o processo contínuo em suas ações que geram vários pequenos resultados ou pequenas ocasiões.

O desenvolvimento do estudo sobre as camadas coautoras revela a diversidade contida nas ações em meio à cidade, onde os choques de interesses e subjetividades geram conflitos e diferentes interações e onde a manifestação dos "[...] mais diferentes gostos, habilidades, necessidades, carências e obsessões" (JACOBS, 2011, p. 161) é responsável pela criação da diversidade na cidade. Há uma crença na "feiura" da diversidade criticada por Jacobs (2011), que escreve que "[...] a diversidade de usos urbanos se assemelha a uma bagunça; e também implica que os lugares marcados pela homogeneidade de usos têm melhor aparência ou são de todo modo mais suscetíveis a um tratamento aprazível ou esteticamente disciplinado" (p. 246). Entretanto, este artigo revelou o quão estreita é a conexão entre estas camadas, sendo responsável por uma vivacidade inegável no espaço da cidade, totalmente oposta à cidade homogênea em estética e uso, promovida pelo urbanismo de topo. E exatamente esta camada de topo pode fatalmente fomentar os pequenos pontos de insurgência como resposta, ao mesmo tempo em que estas insurgências podem fomentar a ação da camada de topo. Salienta-se que atores podem permear entre o topo e a base, podendo diminuir a polarização aqui exposta. As ações insurgentes podem funcionar quase como um casamento entre o que é colocado pelo topo e o que é colocado pela base, de forma que o estudo sobre elas e sobre as pessoas que as compõem é um passo a ser dado como alimentação do conhecimento da formação da cidade.

Dessa forma, a organização e o estudo das camadas coautoras mesclada ao conceito de coautoria pode ser utilizada como ferramenta teórica para os estudos urbanos voltados para a participação. Assim, a compreensão de camadas torna-se uma base ou um método de estudo prévio para tornar mais próxima das necessidades a concepção de um projeto, potencializando os lugares criados. A partir da percepção da existência e da forma na qual cada camada contribui na vida no meio urbano, é possível expandir a visão e o entendimento do que é efetivamente a cidade, afinal, saber o que é a cidade é saber sobre as pessoas que formam-na e constroem-na. 


\section{Referências bibliográficas}

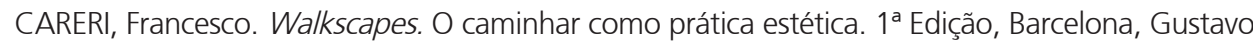
Gili, 2013.

CERTEAU, Michel De. A Invenção do Cotidiano: 1. Artes de Fazer. 22 ed. Petrópolis, RJ: Vozes, 2014.

DURAN, Marília Claret Geraes. Maneiras de Pensar o Cotidiano com Michel De Certeau. In Revista Diálogo Educ., Curitiba, Vol. 7, n²2. Set./Dez. 2007 (p. 115-128). Disponível em <http:// www2.pucpr.br/reol/pb/index.php/dialogo?dd1=1577\&dd99=view\&dd98=pb> Acesso em: 09 jan. 2018.

GEHL, Jan. Cidades para pessoas. São Paulo, Perspectiva, 2013.

GUATTARI, Félix. ROLNIK, Suely. Micropolítica: cartografias do desejo. 12ª ed. Petrópolis, RJ: Vozes. 2013.

HARVEY, David. Cidades rebeldes: do direito à cidade à revolução urbana. São Paulo: Martins Fontes, 2014.

HOLSTON, James. Espaços de cidadania insurgente. In: Revista do patrimônio histórico e artístico nacional. $n^{\circ}$ 24. 1996. (p. 243-253).

JACOBS, Jane. Morte e Vida de Grandes Cidades. 3ªd. São Paulo: Editora WMF Martins Fontes, 2011.

JACQUES, Paola Berenstein. Pensar por montagens. In: JACQUES, Paola Berenstein; PEREIRA, Margareth da Silva (org.). Nebulosas do Pensamento Urbanístico: Tomo I - Modos de Pensar. Salvador: EDUFBA, 2018. (p. 208-234).

Corpografias Urbanas: a memória da cidade no corpo. In: VELLOSO, Monica Pimenta; ROUCHOU, Joelle; OLIVEIRA, Cláudia de. (Orgs.). Corpo: identidades, memórias e subjetividades. Rio de Janeiro: Mauad X/ FAPERJ, 2009. (p-129-139).

JÁUREGUI, Jorge Mario. La ciudad en devenir: economías informales / espacios efímeros. In: Post-it City. Ciudades Ocasionales. Barcelona: CCCB, 2008.

LIMA, Carlos Henrique Magalhães de. A cidade em movimento: práticas insurgentes no ambiente urbano. In Oculum Ensaios. Campinas. Vol. 12, n.1 (p. 39-48). Jan/Jun 2015. (p. 39-48).

A cidade insurgente: estratégias dos coletivos urbanos e vida pública. In: Arquiteturarevista. Vol. 10, n. 1 (p. 31-36). Jan/Jun 2014. (p. 31-36).

MARSHALL, T. H. Citizenship and social class. In: Class, citizenship, and social development. Chicago: University of Chicago Press, 1977. (p.71-134)

ROCHA, Gabrielle Queiroz da. Coautoria Urbana: conflitos entre corpo e cidade-imagem. V!RUS, São Carlos, n. 17, 2018. [online] DOl: 10.4237/virus_journal. Disponível em: <http://www. nomads.usp.br/virus/virus17/?sec=4\&item=7\&lang=pt> Acesso em: 19 jun. 2019.

SANSÃO-FONTES, Adriana. Intervenções temporárias, marcas permanentes: Apropriações, arte e festa na cidade contemporânea. $1^{\text {a }}$ edição. Rio de Janeiro: Casa da palavra, 2013.

SANTOS, Milton. Da totalidade ao lugar. São Paulo: EDUSP, 2008. (p. 163).

VELHO, Gilberto. Metrópole, Cultura e Conflito. In: VELHO, Gilberto (org.). Rio de Janeiro: Cultura, política e conflito. Rio de Janeiro: Jorge Zahar Ed., 2007. (p. 9-29).

VELLOSO, Rita. Pensar por constelações. In: JACQUES, Paola Berenstein; PEREIRA, Margareth da Silva (org.). Nebulosas do Pensamento Urbanístico: Tomo I - Modos de Pensar. Salvador: EDUFBA, 2018. (p. 100-121). 